\title{
The role of gravimorphoses in moss adaptation to extreme environment
}

\author{
Oksana V. LOBACHEVSKA ${ }^{1 *}$ (D), Natalia Ya. KYYAK ${ }^{10}$, Elizabeth L. KORDYUM² (D), \\ Yaroslava D. KHORKAVTSIV ${ }^{1}$ \\ ${ }^{1}$ Institute of Ecology of the Carpathians, National Academy of Sciences of Ukraine, 11 Stefanyka Str., Lviv 79005, Ukraine \\ ${ }^{2}$ M.G. Kholodny Institute of Botany, National Academy of Sciences of Ukraine, 2 Tereschenkivska Str., Kyiv 01601, Ukraine
}

\begin{abstract}
Gravisensitivity of mosses at different stages of their ontogenesis has an adaptive value and contributes to the functional activity of the gametophyte and its stability under extreme conditions in microhabitats. The aim of our research was to determine the participation of gravimorphoses in the adaptive plasticity of mosses depending on thermal conditions of their habitats and UV radiation effect. The objects of the study were sterile cultures of the following moss protonemata: Weissia tortilis, collected in different thermal conditions of Zaporizhzhya and Lviv regions (Ukraine), Bryum caespiticium from Lviv Region (Ukraine), as well as B. caespiticium and Polytrichum arcticum collected in Antarctica (Galindez Island). In all moss cultures, the gravisensitivity of protonemata, the morphological structure and morphogenesis of stolons were analysed. The protonemata of $W$. tortilis from two populations in Ukraine and of $B$. caespiticium from Antarctica and Ukraine, growing under conditions of different UV levels, were compared in terms of their sensitivity to UV radiation. Gravity-dependent morphoses of terrestrial dendrites of $W$. tortilis under arid conditions, branching of apical cells of gravitropic stolons of Antarctic mosses P. arcticum and B. caespiticium as well as the rapid development of shoots on them demonstrate participation of gravimorphogenesis in adaptation of mosses to stressful environmental conditions. Gravisensitivity and ability to form buds at the apex of a gravitropic stolon are considered an important adaptive morphogenetic process. It has been found that plants of $W$. tortilis from Zaporizhzhya Region were more resistant to UV irradiation than those from Lviv Region. Antarctic moss after UV irradiation showed significantly higher antioxidants activity and contained larger amount of phenolic compounds and flavonoids.
\end{abstract}

Keywords: Antarctic, dendrites, gravimorphogenesis, mosses, phenolic compounds, protonemata, ultraviolet irradiation

Article history. Submitted 13 July 2020. Revised 10 November 2020. Published 28 February 2021

Citation. Lobachevska O.V., Kyyak N.Ya., Kordyum E.L., Khorkavtsiv Ya.D. 2021. The role of gravimorphoses in moss adaptation to extreme environment. Ukrainian Botanical Journal, 78(1): 69-79. https://doi.org/10.15407/ukrbotj78.01.069

*Corresponding author (e-mail: ecomorphogenesis@gmail.com)

\section{Introduction}

Gravity, as well as light, is not only an inducer of tropism; it is also an important factor in plant morphogenesis. Various aspects of the morphogenetic action of gravity are combined in a term "gravimorphosis" (Sabovljević et al., 2014; Braun et al., 2018). Studies of gravitropism, a relatively simple growth model, and gravity-dependent moss morphogenetic processes indicate the important role of gravity in plant ontogenesis. A mode of moss spore germination and differentiation of rhizoid and chloronemal stolons, the formation of vegetative and reproductive organs, and the form of a sporogon are gravimorphoses caused by the polarizing effect of gravity (Chaban et al., 1998; Cove et al., 2006; Khorkavtsiv et al., 2015; Lobachevska et al., 2019a). Gravimorphoses are species-specific, change depending on the stages of moss development and environmental factors, and are a widespread adaptive form of growth in the life strategy of bryophytes (Moulia, Fournier, 2009; Kordyum, 2014; Kyyak, Khorkavtsiv, 2016; Lobachevska et al., 2019a). Apart from mosses, the dorsoventral form of tree shoots, wood gravidependent formation, the allocation of lateral buds in orchids and fruiting bodies in fungi are the well known examples of gravimorphoses (Moore et al., 2008; Wojtaszek, 2011).

(C) 2021 O.V. Lobachevska, N.Ya. Kyyak, E.L. Kordyum, Ya.D. Khorkavtsiv. Published by the M.G. Kholodny Institute of Botany, NAS of Ukraine. This is an open access article under the terms of the Creative Commons Attribution License (http://creativecommons.org/licenses/by/4.0/), which permits use, distribution, and reproduction in any medium, provided the original work is properly cited 
Light is a vital environmental factor that is absolutely necessary for photosynthesis; it determines the temperature conditions of the existence of plant organisms, their metabolic processes, growth and distribution. However, UV-rays, which have a detrimental effect on living organisms, fall to the ground as part of sunlight (constituting ca. $6.7 \%$ of that light).

Antarctic moss species are extremophiles adapted to high levels of UV irradiation and the existence in an icy desert, where water is mostly in the state of ice, due to their poikilohydry. However, the dramatic changes in the extreme conditions of Antarctica during the growing season also constrain growth, photosynthesis, distribution and dispersal of bryophytes. The structural and functional organization of Antarctic mosses provides valuable models for understand the nature of adaptive protective reactions, the formation of life forms, resistance to low temperatures and short vegetal period, and features of the photosynthetic activity (Robinson et al., 2005; Smith, 2005; Ochyra et al., 2008; Clarke et al., 2009, 2012; Yoon et al., 2016; Cruz de Carvalho, 2008; Stark, 2017; Lobachevska et al., 2019b; Pizarro et al., 2019). Therefore, the main objective of our research was to study the patterns of gravimorphoses in some moss species growing under different temperature conditions and high levels of UV radiation in Antarctica and the southeastern part of Ukraine.

\section{Materials and methods}

Specimens of moss species Weissia tortilis Spreng., Polytrichum arcticum Sw. ex Brid., and Bryum caespiticium Hedw. were studied. The samples of W. tortilis were collected in Ukraine, in Zaporizhzhya Region and near Lviv (Khorosno village) in Lviv Region. In Zaporizhzhya Region, plants grew in the open field on sandy soils, under conditions of high and prolonged sunlight 100.000-120.000 lx, average daily temperature $32{ }^{\circ} \mathrm{C}$ on the soil surface in summer. In Lviv Region, plants grew on sandy soil among grasses under lower light intensity of 60.000-80.000 lx, and moderate temperature conditions about $24{ }^{\circ} \mathrm{C}$. The samples of mosses B. caespiticium and $P$. arcticum were collected in 2019 on the west coast of Antarctica (Galindez Island) during the $24^{\text {th }}$ Ukrainian Antarctic Expedition organized by the National Antarctic Science Center of Ukraine. Samples of B. caespiticium growing in Roztochia Nature Reserve (Ivano-Frankove village, Yavoriv District, Lviv Region, Ukraine) on moist sandy soil and at light intensity of $60.000-80.000 \mathrm{~lx}$ were also collected to be compared with the Antarctic samples.

\section{Laboratory culture and gravistimulation}

Weissia tortilis protonemata were obtained from spores. Protonemata of B. caespiticium and P. arcticum were obtained by regeneration of isolated leaves and shoots sterilized in $20 \%$ sodium hypochlorite solution ("bleach" mode) on the Knop II agar medium (Lamparter et al., 1996). The sterile cultures of all moss species were grown in Petri dishes under phytotron controlled conditions: photoperiod $16 \mathrm{~h}$, illumination $70 \mu \mathrm{mol} \cdot \mathrm{m}^{-}$ ${ }^{2} \cdot \mathrm{sec}^{-1}$, temperature $20{ }^{\circ} \mathrm{C}$, humidity $90 \%$. Protonemata of different ages were used to study gravisensitivity: 7- and 24-day old of B. caespiticium, 12-day old of $P$. arcticum, and 14-24-day old of $W$. tortilis, as the rate of protonemata growth, cell differentiation, and gametophore development varied in different species.

For gravistimulation, the protonemata balls 1 $\mathrm{mm}$ in diameter of $B$. caespiticium and $W$. tortilis and gametophores $2-4 \mathrm{~mm}$ long of $P$. arcticum were transferred into six Petri dishes (60 $\mathrm{mm}$ diameter) for each of mosses on fresh medium with $0.2 \%$ glucose. For negative gravitropic growth of filaments, the dishes were placed vertically in darkness for 7-10 days. The Petri dishes with vertically grown protonemata were rotated $90^{\circ}$ and maintained in that position for up to 8 hour for gravistimulation. After $8 \mathrm{~h}$, the angles of tops of apical cells were measured with a Motorized Fluorescent Microscope Axio Imager M1 (Carl Zeiss, Germany) in green light.

A size of the angles was a parameter by which the protonemata gravisensitivity was evaluated. The three of dishes in all cultures with gravitropic protonemata of $W$. tortilis, B. caespiticium, and $P$. arcticum were exposed to light and the differentiation of protonemata stolons and the morphological structure of the protonemata were analyzed.

\section{Evaluation of UV-resistance}

The protonemata of two populations of $W$. tortilis, whose locations differed in the UV-level, were compared in terms of their sensitivity to UV-radiation. Fourteen day old protonemata of the same size were irradiated with a UV lamp OSRAM (Germany) with a power of 150 $180 \mathrm{~W}$. The total radiation power of $400-320 \mathrm{~nm}$ was measured with a luxmeter UVAB WALCOM UV - 340B. Energy capacity from 1 to $4 \mathrm{~kW}$ was obtained depending on the duration of irradiation (Clarke, Robinson, 2008). The lethal doses $\mathrm{LD}_{50}$ and $\mathrm{LD}_{90}$ for assessing the level of cell tolerance were determined by the percentage of protonemata that survived 10 days after UV-irradiation. 
The sterile cultures of the 14-day old protonemata of $B$. caespiticium from Ukraine and Antarctica were irradiated similarly to those of $W$. tortilis.

\section{Determination of the antioxidant activity (AA)}

The resistance of protonemata with gametophores of B. caespiticium to UV-irradiation was detected by the level of AA using the Brand-Williams method (BrandWilliams et al., 1995).

The solution of DPPH (2,2-Diphenyl-1picrylhydrazyl) (Sigma-Aldrich, Missouri, USA) in methanol $(200 \mu \mathrm{M})$ was freshly prepared. A methanolic plant extract $(0.2 \mathrm{~mL})$ was added to $2.8 \mathrm{~mL}$ of DPPH solution. After $30 \mathrm{~min}$ at room temperature in the dark, the absorbance was recorded on UV/VIS Spectrophotometer (Specord 210 Plus, Analytik Jena, Germany) at $517 \mathrm{~nm}$.

The percentage of reduction of the solution optical density was determined by the formula:

$$
(\%)=\left[\left(A_{0}-A_{1}\right) /\left(A_{0}\right)\right] \times 100,
$$

$\mathrm{A}_{0}$ - the optical density of the DPPH methanolic solution; $\mathrm{A}_{1}$ - the optical density of the DPPH methanolic solution after addition of the plant extract.

\section{Determination of the total phenolic content (TPC)}

The TPC was determined using the methods of Clarke and Robinson (2008) and Anahita et al. (2015). Fresh plant material $(1 \mathrm{~g})$ was homogenized, added 0.5 $\mathrm{mL}$ methanol, $7.0 \mathrm{~mL}$ distilled water and $0.5 \mathrm{~mL}$ FolinDenis' reagent (Sigma-Aldrich, Missouri, USA). After $3 \mathrm{~min}, 1 \mathrm{~mL}$ of saturated sodium carbonate solution was added and the volume was adjusted to $10 \mathrm{~mL}$ with distilled water. After $60 \mathrm{~min}$ the absorbance was recorded using a spectrophotometer (Specord 210 Plus, Analytik Jena, Germany) at $730 \mathrm{~nm}$. Phenolic compounds content was expressed as mg chlorogenic acid equivalent per $1 \mathrm{~g}$ dry weight.

\section{Determination of the total flavonoids contents (TFC)}

The TFC was determined by the method of Pękal and Pyrzynska (2014). Fresh samples of $0.1 \mathrm{~g}$ were weighed, and $1.0 \mathrm{~mL}$ methanol (Merck) was used to extract flavonoids for $24 \mathrm{~h}$. These samples were further centrifuged at $3000 \mathrm{~g}$. The total flavonoids content was determined using $\mathrm{AlCl}_{3}(2 \%, \mathrm{w} / \mathrm{v})$. The absorbance of the mixture solution was measured with a spectrophotometer (Specord 210 Plus, Analytik Jena, Germany) at 412 $\mathrm{nm}$. Flavonoids content was expressed as $1 \mathrm{mg}$ rutin equivalent per $1 \mathrm{~g}$ dry weight.

\section{Statistical analysis}

All experiments were repeated at least three times. For each moss species, 25 protonemata and 10 stolons in each

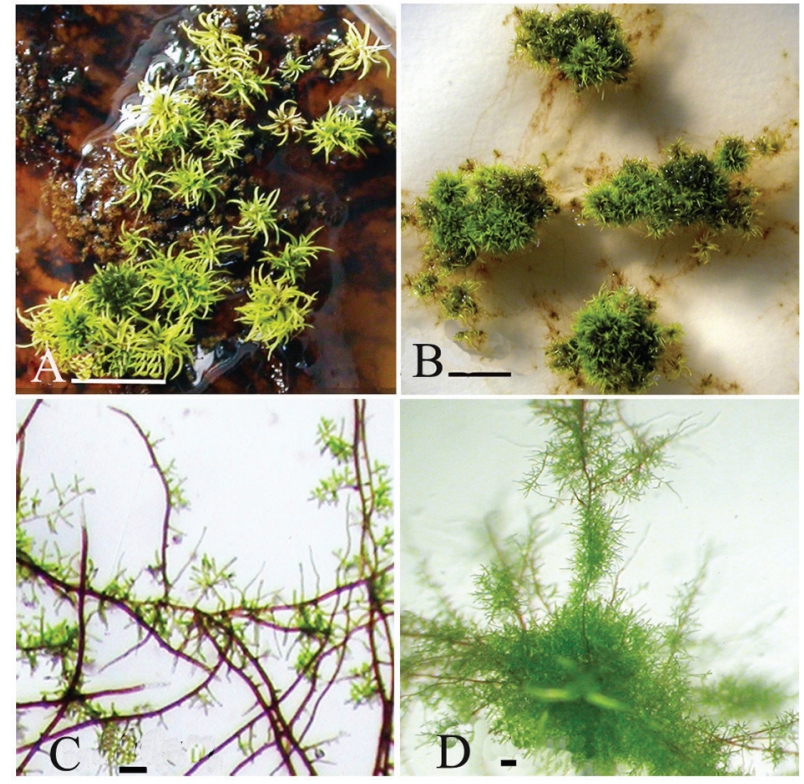

Fig. 1. Mats of Weissia tortilis from Lviv Region (A, C) and Zaporizhzhya Region (B, D). A: loose protonemata with gametophores. C: caulonema stolons with short, not very branched dendrite. B: groups of tightly placed gametophores in the protonemata, $\mathrm{D}$ : intensive formation of dendrites covering the caulonema. Scale bars: $4 \mathrm{~mm}(\mathrm{~A}, \mathrm{~B}), 100 \mu \mathrm{m}(\mathrm{C}, \mathrm{D})$

protonema in six Petri dishes were analyzed. Quantitative data were reported as means \pm standard deviation (SD). Statistical significance was checked using Student's $t$-test and considered significance with the $P$ value less than 0.05 (Baran, Warry, 2008).

\section{Results}

Life strategy is one of the factors that may influence the gravitational system of moss gametophyte. Weissia tortilis is a perennial shuttle, whose life cycle is strictly determined by seasonal fluctuations and stressful periods, the growth form is a low loose turf, duration of the existence in ecotope is quite high (more than 5 years). This moss is predominantly able to survive unfavorable conditions at the stage of perennial protonemata and to form turfs at the site when the conditions become favourable.

Samples of $W$. tortilis from Zaporizhzhya and Lviv regions were characterized by distinctive differences that are important for their existence in different climatic zones. The protonemata of the Lviv population was loose, with a cover of small dendrites, but gametophores that retained moisture and provided photosynthetic activity (Fig. 1, A, C). 


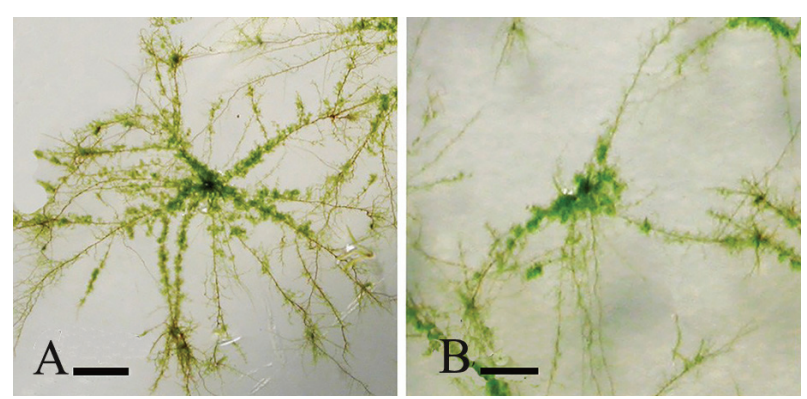

Fig. 2. Protonemata of Weissia tortilis from Zaporizhzhya Region (A) and from Lviv Region, Khorosno village (B). Scale bar: $40 \mu \mathrm{m}$

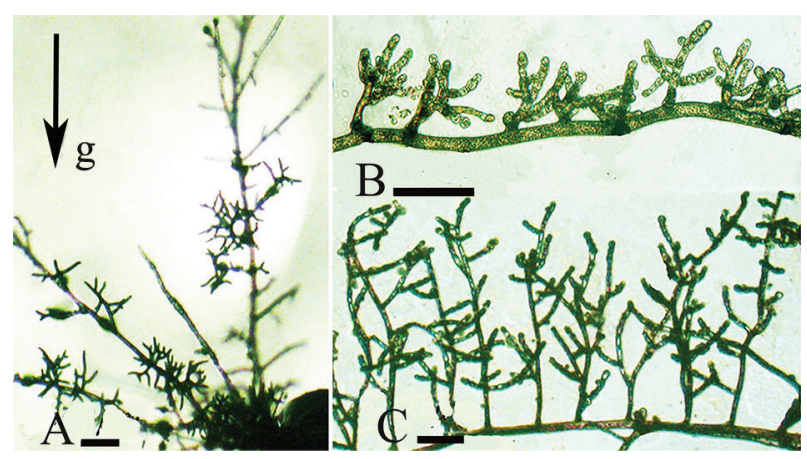

Fig. 3. Caulonemal stolons of Weissia tortilis with chloronemata dendrites. A (from Lviv Region, Khorosno village): a gravisensitive stolon with short dendrites. B, C (from Zaporizhzhya Region) branched dendrites. Vertical arrow shows the direction of gravity. Scale bar: $60 \mu \mathrm{m}$

In the protonemata from Zaporizhzhya Region, gametophores were occasionally developed; they were arranged in groups fairly distant from each other (Fig. 1, B). Caulonema stolons dominated, they were constantly growing lengthwise, often branching, as a result a thick cover of short chloronema assimilating dendrites was formed (Fig. 1, D).

Protonemata from Zaporizhzhya Region grown in the culture are distinguished by both long 4-7 caulonema stolons oriented in different directions and the intensive formation of lateral branched dendrites, which thickly covered the caulonema (Fig. 2, A). Protonemata grown from spores collected in Lviv Region, contained 2-3 long caulonema stolons and short, not very branched, dendrite-type chloronema (Fig. 2, B). The higher intensity of white light stimulated the branching of the caulonema intercalary cells of both samples.

Long caulonema stolons of $W$. tortilis grew plagiotropically at a shallow depth and responded to the gravitational vector. Stolons of the chloronema type - dendrites were raised on the soil surface due to the negative gravitropic growth of the caulonema and its
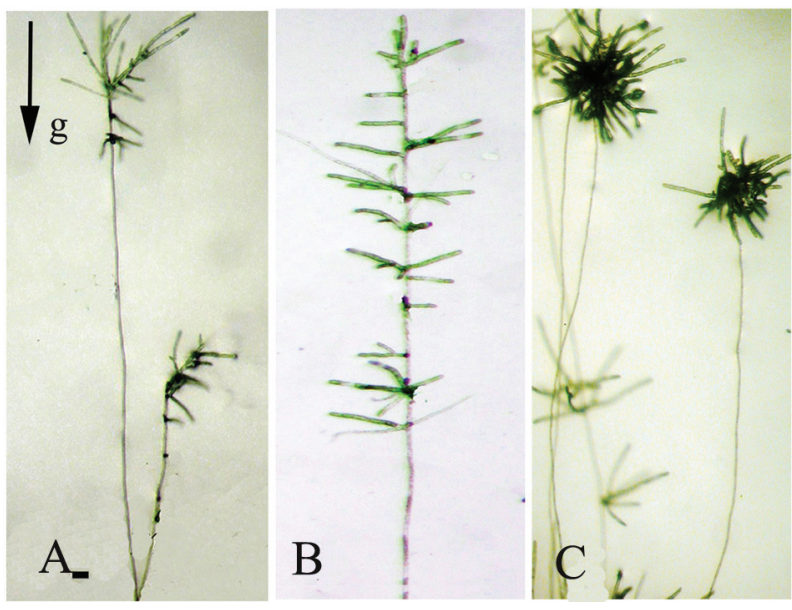

Fig. 4. Branching of apical cells of gravitropic stolons of Bryum caespiticium from Antarctica (A), Lviv Region (B), and Polytrichum arcticum (C). Vertical arrow shows the direction of gravity. Scale bar: $100 \mu \mathrm{m}$

branching (Fig. 3, A-C). Lateral branches grew about 10 times slower than caulonema, but they often made up short branches on the surface of caulonema stolons (Fig. 3, B, C). A continuous assimilation cover was formed from the chloronema dendrites.

Gravisensitivity of $W$. tortilis from different localities did not differ significantly in the laboratory culture. A gravitropic band occurred in the caulonema apical cell, which contained few plastids. Numerous amyloplasts sedimented in the lower side of the subapical cell initiating the gravitropism response (Lobachevska et al., 2019a).

The terrestrial chloronemata dendrites, as assimilating and photoprotective morphological structures, initiated from the gravisensitive caulonema cells. Underground caulonema stolons and rhizoids, which provided protonemata anchoring in the substrate and water retention, were also initiated from caulonema. Weissia tortilis gametophyte survival in ecosystems with a lack of moisture and high energy radiation is directly connected with the variability of gravimorphoses (Lobachevska et al., 2019a). Stolons, which grew upwards and promoted protonemata survival at extremely high temperatures, were also found in the cultures from Zaporizhzhya Region. Undoubtedly, the gravi-dependent diversity of the life form of $W$. tortilis gametophyte enables the moss to adapt to environmental conditions of its habitats.

To understand how moss gravisensitivity is manifested under extreme conditions, where sharp climatic changes often occur during short vegetation periods, the gravireactions of $B$. caespiticium and Polytrichum arcticum species common in Antarctica have been analyzed.

Ukrainian Botanical Journal, 2021, 78(1) 


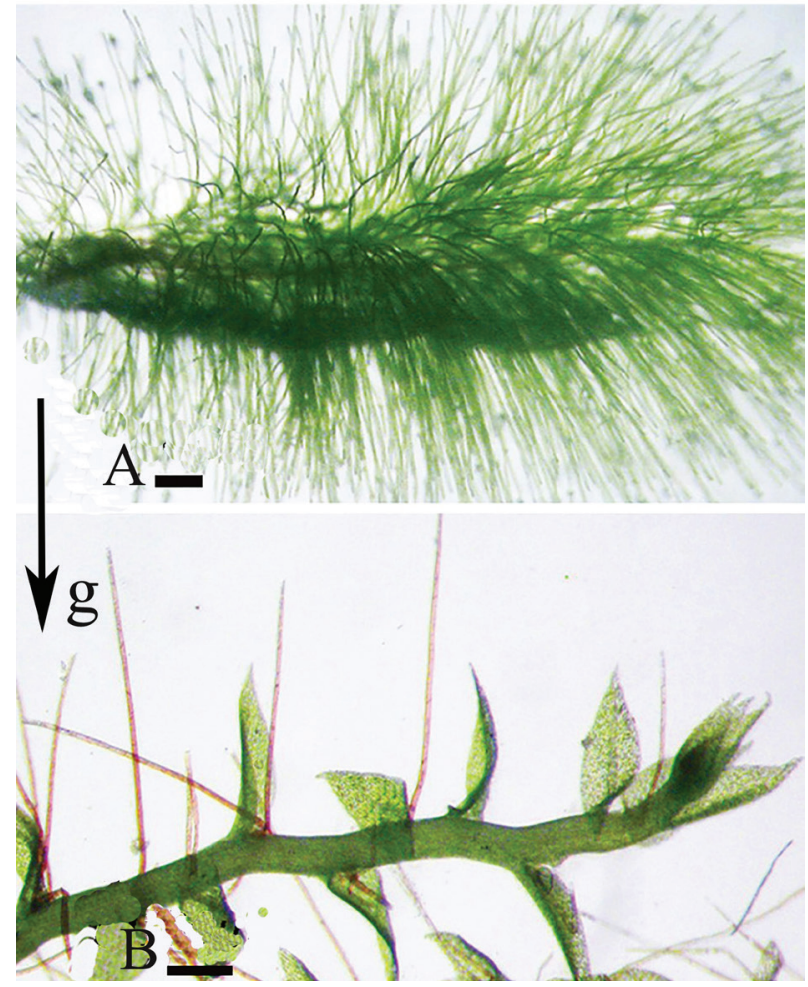

Fig. 5. Regenerative protonemata of Polytrichum arcticum. A: nonsensitive to gravity chloronemata developed from cells of an isolated leaf. B: gravitropic caulonemal stolons growing from shoot cells. Vertical arrow shows the direction of gravity. Scale bar: $100 \mu \mathrm{m}$

In $B$. caespiticium, gametophores and the secondary caulonema are gravisensitive. Gravitropic growth of the secondary protonema from moss shoots from Antarctica was slower than in moss shoots from Ukraine used as control. After 20-24 h after gravistimulation, an angle of the caulonema apical cell band was $30-35^{\circ}$, and after 40 $\mathrm{h}$ it slowly increased to $75^{\circ}$. In control, gravitropic stolons grew at an angle of $60^{\circ}-70^{\circ}$ after $10 \mathrm{~h}$ of gravistimulation. The concentration of amyloplasts in the top of an apical cell of the protonema stolon was a characteristic feature of Antarctic B. caespiticium, which is not typical for gravisensitive moss species. For example, there are only 2-3 amyloplasts in the top of an apical cell of Ceratodon purpureus and Physcomitrella patens, the rest of plastids are located in the subapical part of the cell (Chaban et al., 1998; Kern, Sack, 1999; Kern et al., 2005). This may be one of the reasons for the slower gravitropic reaction of B. caespiticium from Antarctica. Therefore, in our opinion, the dissimilar sensory system in B. caespiticium from Antarctica is important in extreme habitat conditions, but that suggestion requires further studies.

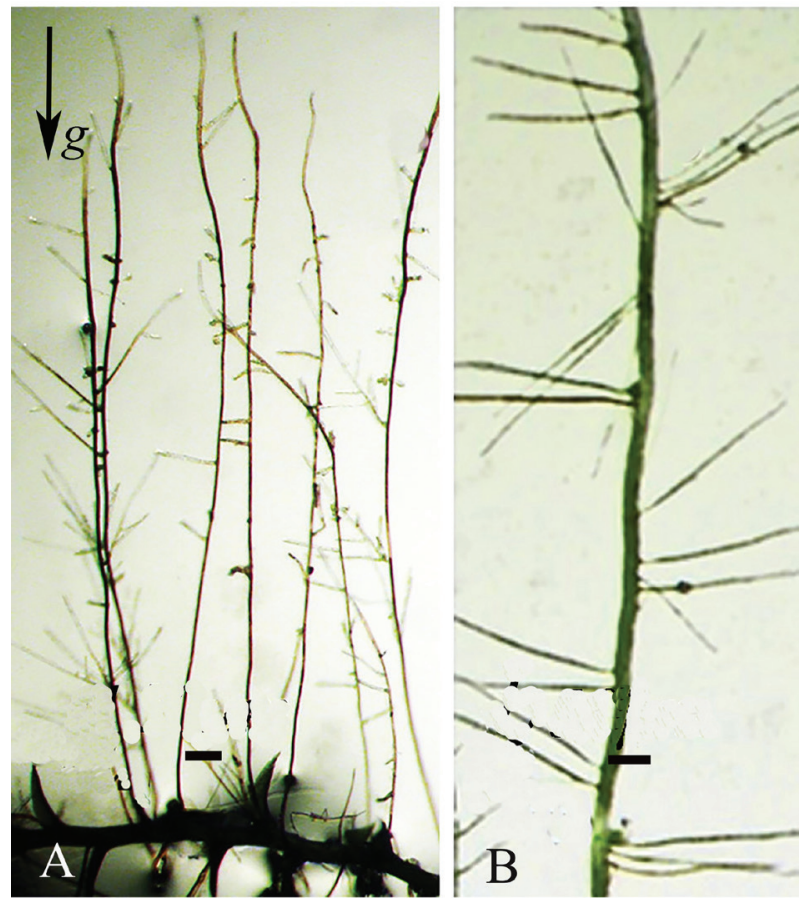

Fig. 6. Gravitropic stolons from branched Polytrichum arcticum shoots. A: a separate stolon with lateral branches; B: lateral branches formed predominantly at right angles to the main stolon. Vertical arrow shows the direction of gravity. Scale bar: $50 \mu \mathrm{m}$

Apical cells of gravitropic stolons of both B. caespiticium and Polytrichum arcticum (Fig. 4, A, B) intensively branched on the light, resulting in the formation of protonemata from short chloronema stolons on their tops, which could disintegrate into numerous 2-3-celled fragments. Fragmentation, as a form of asexual reproduction, enables one moss plant to produce genetically identical offspring most adapted to the syrvival in and fast colonization of large areas. Bud primordia that developed in gravisensitive gametophores were also initiated on the braches.

In $P$. arcticum from Antarctica, only the secondary caulonema stolons were gravisensitive. Stolons formed as a result of shoot regeneration, which is one of the methods of rapid vegetative propagation of mosses in nature. Chloronemal stolons, which were obtained from isolated young leaves or their small fragments, did not respond to gravity (Fig. 5, A, B).

Buds of gametophores initiated rather on the gravitropic protonema of $P$ arcticum, than on the non-gravistimulated one, and the larger protonemata developed as well. Under natural conditions, morphological variations of protonema stolons promote to form more vigorous protonemata and then the moss 
Table 1. Viability of Weissia tortilis protonemata depending on the UV-irradiation intensity

\begin{tabular}{|c|c|c|}
\hline \multirow{2}{*}{ Intensity of $\mathrm{UV}$-irradiation, $\mathrm{kW} / \mathrm{m}^{2}$} & \multicolumn{2}{|c|}{ Protonemata surviving after UV-irradiation, $\%$} \\
\cline { 2 - 3 } & from Zaporizhzhya Region & from Lviv Region \\
\hline 1.0 & $100.0 \pm 1.3$ & $60.0 \pm 4.5$ \\
\hline 2.0 & $90.0 \pm 4.3$ & $60.0 \pm 4.7$ \\
\hline 3.0 & $70.0 \pm 3.8$ & $10.0 \pm 2.7$ \\
\hline 4.0 & $10.0 \pm 1.8$ & $2.0 \pm 0.3$ \\
\hline 5.0 & $0.7 \pm 0.2$ & - \\
\hline
\end{tabular}

cover to occupy the area of distribution. It is important to note that $30 \%$ branches of the gravitropic protonema of $P$. arcticum initiated approximately at right angles to the main stolon (Fig. 6, A) and grew plagiotropically without showing gravitropism (Fig. 6, B).

Such type of branching facilitates the horizontal overgrowth of the underground caulonema, which secures protonemata in the substrate, stores nutrients and provides water retention in terrestrial gametophytes. Thus, on the same stolon of the caulonema there are gravisensitive apical cells and lateral branches that do not respond to gravity. In general, a life form of the moss gametophyte, adapted to the ecological factors of habitation, was formed with the involvement of the gravitational signalling system and the morphological heterogeneity of stolons.

High resistance to UV-irradiation and tolerance to water scarcity of $W$. tortilis ensures its wide distribution in arid and subarid conditions of southern Ukraine and Central Asia. It was established that $W$. tortilis plants from Zaporizhzhya Region were more resistant to UV-radiation than those from Lviv vicinity. Under the condition of $\mathrm{LD}_{90}$ for the Lviv population, $70 \%$ of protonemata from Zaporizhzhya Region survived (Table $1)$.

Underground caulonema stolons of the W. tortilis protonemata, unlike the chlorophyll-bearing cells of the dendrites, have a specific brown-red coloration of the cell walls caused by the presence of phenolic compounds. The latter, as components of the adaptation system of the bryophytes to stress (Tuba et al., 2011; Iqbal et al., 2019), could increase the resistance of moss protonemata to UV-radiation. Protonemata (shoots and protonema) of Antarctic mosses differ by much more intense brownred coloration. Obviously, a predominantly dark colour contributes to better absorption of sunlight and heat retention.

To determine the potential of moss resistance to stress factors, we compared the levels of AA and TPC in the samples of gametophytes of $B$. caespiticium from

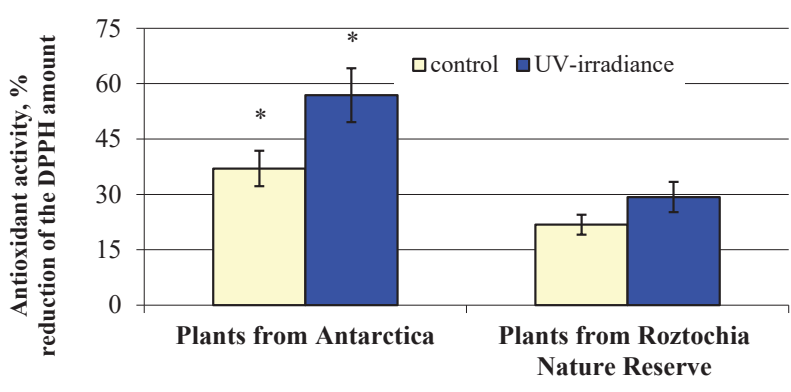

Fig. 7. Antioxidant activity of Bryum caespiticium gametophytes from Antarctica and Roztochia Nature Reserve in Lviv Region. $(\mathrm{x} \pm \mathrm{SD}, \mathrm{n}=4) . *$ - Difference compared to plant from Lviv vicinity is statistically reliable at $P<0.05$

Table 2. Total phenolic content and total flavonoids content in Bryum caespiticium 14-day old protonemata from different locations after irradiation with a UV lamp (4.0 $\mathrm{kW}), \mathrm{t}(\mathrm{x} \pm \mathrm{SD}, \mathrm{n}=4)$

\begin{tabular}{|l|c|c|}
\hline \multirow{2}{*}{$\begin{array}{c}\text { Variants of } \\
\text { experiments }\end{array}$} & Total phenolic content & Total flavonoids content \\
\cline { 2 - 3 } & \multicolumn{2}{|c|}{$\mathrm{mg} / \mathrm{g}$ dry weigh } \\
\hline Plants from Galindez Island (Antarctica ) \\
\hline Control & $4.48 \pm 0.55$ & $2.98 \pm 0.31$ \\
\hline After UV-irradiation & $6.12 \pm 0.58^{*}$ & $4.52 \pm 0.48^{*}$ \\
\hline Plants from Roztochia Nature Reserve (Lviv Region, Ukraine) \\
\hline Control & $3.23 \pm 0.46$ & $2.37 \pm 0.32$ \\
\hline After UV-irradiation & $3.88 \pm 0.29$ & $3.12 \pm 0.26$ \\
\hline
\end{tabular}

* - Difference compared to plant from Roztochia Nature Reserve is statistically reliable at $P<0.05$.

two extremely different climatic zones - Antarctica and Roztochia Nature Reserve of Lviv Region (Fig. 7).

It was found that TPC and TFC differed in the moss protonemata from the two localities. Antarctic moss contained the significantly higher amount of phenolic compounds and flavonoids, which increased after UVirradiation (Table 2).

The TPC and TFC in the moss samples from the Roztochia Nature Reserve area (Lviv Region) was lower and increased insignificantly after UV-irradiation. Thus, the ecophysiological plasticity of B. caespiticium gametophytes ensures their stability under extreme conditions of Antarctica. 


\section{Discussion}

Studies of morphological and metabolic processes at the different stages of moss ontogenesis under gravistimulation and abiotic stress complement the knowledge about the protective adaptive mechanisms of plants. A fairly simple structural and functional organization of mosses is a convenient model system for studying the nature of plant stress tolerance (Lobachevska et al., 2005, 2019c; Lobachevska, 2013; Tuba et al., 2011; Glime, 2006; Müller et al., 2016). It has been established that a long-term protonema stage in $W$. tortilis, which persists throughout the life cycle, is characterized by specific differentiation of morphologically different chloronema and caulonema cells and the formation of lateral branches of the chloronema type (dendrites). Plasticity of the morpho-physiological structure of a gametophyte under the influence of ecological factors facilitates the survival of mosses in stressful thermal conditions of the habitat (Glime, 2006).

It was established that formation of large protonemata of $W$. tortilis distributed in dry, sunny places, where sporogonia are rarely developed, depends on both its ability to form a regenerative protonema during the year and its capacity to adapt to changing environmental conditions and to withstand them. The ground positive phototropic chloronema, which densely covers the caulonema stolons, initiated from the first 2-4-celled branches of caulonema due to their gravisensitivity. The gravi-dependent growth of the protonemata and its morphological variability is considered as an adaptive trait that has evolved due to gravity and adjustment to high temperature and moisture deficiency. Rapid formation of dendrites on negatively gravitropic stolons creates an assimilatory protonema over the substrate surface to increase the area and viability of moss protonemata. Lower sensitivity of $W$. tortilis cells to solar irradiation is supposed to be ensured by the presence of short branched chloronema stolons and plastid-filled cells that shield the caulonema stolons from damage. The similar morphology of protonemata, which protects cell components from sunlight, has been described in Ceratodon purpureus and other species of the family Pottiaceae, but only under water deficiency and high light intensities (Glime, 2006).

After UV-irradiation, the most densely shielded cells of $W$. tortilis caulonema remained viable, and their high regenerative capacity and polarized apical growth contributed to survival of the moss turf. In addition, the formation of thick chloronemal turf, as an additional growth form, has become a barrier against the harmful effects of UV-rays. It is possible that the specificity of such a function led to morphological changes of chloronema incompatible with gravitropism. Therefore, the morphological organization of the $W$. tortilis protonemata was largely formed according to the habitation conditions, in particular, to the lack of moisture, high temperatures and doses of UV-irradiation. Perhaps this is why during the caulonema branching at the stage of differentiation of the first cells of chloronema, a short-term induction of the gravisensory system occurred as an ecological necessity of gravitropism for the formation of a system of photoprotection and assimilation involving dendrites. Gravi-responses of Antarctic mosses are an obvious example of how the variability of gravitropism depends on the environment, mainly on humidity and temperature factors. The major natural stressors for Antarctica plants are low temperatures, lack of moisture, short growing season, and UV-radiation (Waterman et al., 2018).

It has been established earlier that B. pseudotriquetrum plants collected in Antarctica exhibited specific gravimorphoses (Lobachevska et al., 2019a). In Antarctic B. pseudotriquetrum there were gravisensitive shoots and numerous nidifugous buds were formed in the leaf axils, which ensured moss reproduction during the short growing season. In ecomorphs from Lviv Region, buds developed on rhizoids. Gravi-responses of B. pseudotriquetrum, due to the accelerated development of nidifugous buds in shoots, can be important for moss survival in Antarctica and for rapid distribution without spore formation and developed protonema under stress conditions.

Mosses respond to altered gravity depending on the level of cell differentiation at different stages of ontogenesis (Cove et al., 2006). It is most likely that extreme variations in humidity and temperature limit the protonema development, so the reaction of plants to gravity is manifested only during the growing season and at the dominant stage of gametophores. In P. arcticum, development of secondary caulonema, which is formed by shoot regeneration, is one of the modes of moss propagation in nature. As moss sexual reproduction is not widespread in Antarctica, the primary chloronema from spores is rare, and the regenerative chloronema is especially sensitive to temperature changes, the gravisensory system does not function at this stage.

In our opinion, gravisensitivity and gravimorphogenesis of the secondary caulonema, which is better protected from UV-irradiation and water deficiency, are common and characteristic features of B. caespiticium and $P$. arcticum. In experimental studies, cells branched 
on the tops of gravitropic stolons, and a new protonema formed on each of branches. Under natural conditions, such an additional functional organ greatly accelerates the growth and distribution of the species gametophytic protonemata. Later, buds formed on the branches and gravisensitive gametophores developed. Gravisensitivity and ability to form buds at the top of a gravitropic stolon are considered as important adaptive morphogenetic processes.

Bryophytes are dominants among higher plants in locations with high levels of UV-radiation in Antarctica due to their adaptive morpho-physiological strategy for the defense of its action (Glime, 2006). Under highenergy irradiation (alpine and subalpine zones, polar regions), mosses have greater photosynthetic capabilities and higher thresholds of sensitivity to excess light than those growing at low light intensities (Robinson et al., 2003; Newsham, Robinson, 2009; Robinson, Waterman, 2014). Resistance to solar irradiation is supported by both the morphological plasticity of moss gametophytes and the efficiency of functioning of their repair systems (Medina et al., 2015), in particular, the system of protection against oxidative degradation.

The activity of low-molecular antioxidants of Antarctic B. caespiticium gametophytes was found to be higher as compared to the moss population in Lviv Region. In the experiment under the influence of UV-irradiation, the level of AA in the Antarctic moss population increased significantly, indicating their more effective protective mechanisms associated with a higher pool of antioxidants and the activation of their latent form.

A characteristic feature of mosses is the high content of phenolic compounds (PC) (Iqbal et al., 2019), which are crucial for the formation of plant tolerance to stress (Cruz de Carvalho et al., 2017). PC counteract oxidative stress because they are able to function as scavengers of free radicals and reactive oxygen species, maintain the cell's internal environment in a restored state, and positively affect the activity of antioxidant enzymes ( $\mathrm{Su}$ et al., 2007). The red-brown coloration of cell walls of caulonema stolons and shoots is evidence of the presence of TFC, which screen vital cellular structures from damage, have a photo-protective effect, and increase the resistance of plants to UV-radiation. The higher TFC in samples of B. caespiticium from Antarctica, compared to plants of middle latitudes, indicates their decisive role in the protective systems under stressful conditions and UV irradiation. Therefore, the accumulation of lowmolecular antioxidants in cells underlies to a great extent the resistance of $B$. caespiticium from Antarctica to
UV-irradiation and a high potential of the physiological state that preserves the viability of gametophytes under stressful conditions.

\section{Conclusions}

Gravity-dependent morphoses of terrestrial dendrites of $W$. tortilis in arid propagation conditions and formation cells branched on the tops of gravitropic stolons of Antarctic mosses $P$. arcticum and B. caespiticium as well the rapid development of shoots on it are a manifestation of the participation of gravimorphogenesis in the moss adaptation to stressful environmental conditions.

The gravisensitivity and gravimorphogenesis of the secondary caulonema, which is the most stable and plastic stage of the protonemata development of the investigated mosses under ecological stress. Gravimorphoses enrich the phenotypic plasticity of mosses, which ensures their viability and formation of the moss cover in the extreme environment.

Resistance to UV-radiation is stipulated by both the morphological variability of gametophytes and the effectiveness of the protective systems against oxidative degradation, in particular the accumulation of low-molecular antioxidants. A high antioxidant potential of phenolic compounds, especially flavonoids, B. caespiticium should be considered as a key mechanism for UV tolerance.

\section{Acknowledgments}

This work was supported by the Special Complex Program of the National Academy of Sciences of Ukraine on Scientific Space Research in 2018-2022 years.

\section{References}

Anahita A., Asmah R., Fauziah O. 2015. Evaluation of total phenolic content, total antioxidant activity, and antioxidant vitamin composition of pomegranate seed and juice. International Food Research Journal, 22: 1212-1217. https://doi.org/10.4172/2327-5146.1000164

Baran E., Warry F. 2008. Simple data analysis for biologists. Phnom Penh, Cambodia: World Fish Center and the Fisheries Administration, 67 p. https://digitalarchive. worldfishcenter.org/handle/20.500.12348/1494 and http:// pubs.iclarm.net/resource centre/WF 1817.pdf 
Brand-Williams W., Cuvelier M.E., Berset C. 1995. Use of a free radical method to evaluate antioxidant activity. $L W T-$ Food Science and Technology, 28(1): 25-30. https://doi. org/10.1016/S0023-6438(95)80008-5

Braun M., Böhmer M., Häder D.-P., Hemmersbach R., Palme K. 2018. Gravitational Biology 1. Gravity sensing and graviorientation in microorganism and plants. Springer Briefs in Space Life Sciences. Eds G. Ruyters, M. Braun. Berlin: Springer, 134 pp.

Chaban Ch.I., Kern, V.D., Ripetsky R.T., Demkiv O.T., Sack, F. 1998. Gravitropism in caulonemata of the moss Pottia intermedia. Journal of Bryology, 20: 287-299. https://doi. org/10.1179/jbr.1998.20.2.287

Clarke L.J., Robinson S.A. 2008. Cell wall-bound ultraviolet-screening compounds explain the high ultraviolet tolerance of the Antarctic moss, Ceratodon purpureus. New Phytologist, 179: 776-783. https://doi. org/10.1111/j.1469-8137.2008.02499.x

Clarke L.J., Ayre D.J., Robinson S.A. 2009. Genetic structure of East Antarctic populations of the moss Ceratodon purpureus. Antarctic Science, 21: 51-58. https://doi.org/10.1017/ $\underline{\mathrm{S} 0954102008001466}$

Clarke L.J., Robinson S.A., Hua Q., Ayre, D.J., Fink D. 2012. Radiocarbon bomb spike reveals biological effects of Antarctic climate change. Global Change Bioljgy, 18: 301310. http://dx.doi.org/10.1111/j.1365-2486.2011.02560.x

Cove D., Benzanilla M., Harries P., Quatrano R. 2006. Mosses as model systems for the study of metabolism and development. Annual Review of Plant Biology, 57:497-520. https://doi.org/10.1146/annurev.arplant.57.032905.105338

Cruz de Carvalho M.H. 2008. Drought stress and reactive oxygen species: Production, scavenging and signaling. Plant Signaling \& Behavior, 3(3): 156-165. https://doi. org/10.4161/psb.3.3.5536

Cruz de Carvalho R., Catalá M., Branquinho C., Marques da Silva J., Barreno E. 2017. Dehydration rate determines the degree of membrane damage and desiccation tolerance in bryophytes. Physiologia Plantarum, 159(3): 277-289. https://doi.org/10.1111/ppl.12511

Glime J.M. 2006. Bryophyte ecology, vol. 1: Physiological ecology. Available at: https://digitalcommons.mtu.edu/ bryophyte-ecology/

Iqbal Z., Javed M., Gull S., Mahmood M.H.-R., Hai Z. 2019. Total phenolic contents of two varieties of Crocus sativus and their antioxidant activity. International Journal of Biosciences, 14(3): 128-132. http://dx.doi.org/10.12692/ ijb/14.3.128-132

Kern V.D., Schwuchow J.M., Reed D.M., Nadeau, J.A., Lucas J., Skripnikov A., Sack F.D. 2005. Gravitropic moss default to spiral growth on the clinostat and in microgravity during spaceflight. Planta, 2221: 149-157. https://doi. org/10.1007/s00425-004-1467-3

Kern V., Sack F. 1999. Irradiance-dependent regulation of gravitropism by red light in protonemata of the moss Ceratodon purpureus. Planta, 209: 299-307. https://doi. org/10.1007/s004250050636
Khorkavtsiv Y.D., Kordyum E.L., Lobachevska O.V., Kyyak N.Y., Kit N.A. 2015. Ukrainian Botanical Journal, 72(6): 588-595. [Хоркавців Я.Д., Кордюм Є.Л., Лобачевська О.В., Кияк Н.Я., Кіт Н.А. 2015. Галуження протонеми Ceratodon purpureus в умовах зміненої гравітації. Украӥнський ботанічний журнал, 72(6): 588-595]. Available at: http://nbuv.gov.ua/UJRN/ UBJ $2015 \quad 72 \quad 6 \quad 10$

Kordyum E.L. 2014. Plant cell gravisensitivity and adaptation to microgravity. Plant Biology, 16(1): 79-90. https://doi. org/10.1111/plb.12047

Kyyak N.Y., Khorkavtsiv Y.D. 2016. Space Science and Technology, 22(4): 58-66. [Кияк Н.Я., Хоркавців Я.Д. 2016. Оцінка оксидативного стресу моху Pohlia nutans (Hedw.) Lindb. залежно від впливу гравітації. Космічна наука і технологія, 22(4): 58-66]. https://doi. org $/ 10.15407 / \mathrm{knit} 2016.04 .058$

Lamparter T., Esch, H., Cove D., Hughes, J., Hartmann E. 1996. Aphototropic mutants of the moss Ceratodon purpureus with spectrally normal and with spectrally dysfunctional phytochrome. Plant Cell Environment, 19(5): 560-568. https://doi.org/10.1111/j.1365-3040.1996. tb00389.x

Lobachevska O., Kyjak N., Khorkavtsiv O., Dovgalyuk A., Kit N., Klyuchivska O., Cove D. 2005. Influence of metabolic stress on the inheritance of cell determination in the moss, Pottia intermedia. Cell Biology International, 29(3): 181186. https://doi.org/10.1016/j.cellbi.2005.02.001

Lobachevska O.V. 2013. Chornomorskyi Botanichnyi Zhurnal, 10(1): 48-60. [Лобачевська О.В. 2013. Бріофіти як модель вивчення екофізіологічної адаптації до умов середовища. Чорноморськийботанічнийжурнал, 10(1): 48-60]. http://dx.doi.org/10.14255/2308-9628/14.101/6

Lobachevska O.V., Kyyak N.Y., Khorkavtsiv Y.D. 2019a. Space Science and Technology, 25(2): 60-70. [Лобачевська О.В., Кияк Н.Я., Хоркавців Я.Д. 2019a. Морфофункціональні властивості протонеми моху Weissia tortilis Spreng. 3 різною чутливістю до гравітації. Космічна наука і технологія, 25(2): 60-70]. https://doi.org/10.15407/knit2019.02.060

Lobachevska O., Khorkavtsiv Y., Kyyak N., Kordyum E., Matveeva N. 2019b. Gravitropism provides an adaptation of mosses to Antarctica condition. In: IX International Antarctic Conference Dedicated to the $60^{\text {th }}$ anniversary of the signing of the Antarctic Treaty in the name of peace and development of international cooperation, Kyiv, Ukraine, 14-16 May, 2019. Kyiv, pp. 219-221.

Lobachevska O.V., Kyyak N.Y., Rabyk I.V. 2019c. Ecological and physiological peculiarities of bryophytes on a posttechnogenic salinized territory. Biosystems Diversity, 27(4): 342-348. https://doi.org/10.15421/011945

Medina R., Yang L., Wang L.-S., Guo S.L., Hylander K., Goffinet B. 2015. DNA based revised geographic circumscription of species of Physcomitrella s.l. (Funariaceae): P. patens new to East Asia and P. magdalenae new to East Africa. Bryologist, 118(1): 2231. http://dx.doi.org/10.1639/0007-2745-118.1.022

Moore D., Gange A.C., Gange E.G., Boddy L. 2008. Fruit bodies: Their production and development in relation to 
environment, In: Ecology of saprotrophic Basidiomycetes, vol. 28. Amsterdam: Elsevier Ltd., pp. 79-103.

Moulia B., Fournier M. 2009. The power and control of gravitropic movements in plants: a biomechanical and systems biology view. Journal of Experimental Botany, 60(2): 461-486. https://doi.org/doi:10.1093/jxb/ern341

Müller S.J., Desirée D., Gütle J.P., Jacquot R., Reski R. 2016. Can mosses serve as model organisms for forest research? Annals of Forest Science, 73: 135-146. http://dx.doi. org/10.1007/s13595-015-0468-7

Newsham K.K., Robinson S.A. 2009. Responses of plants in polar regions to UVB exposure: a meta-analysis. Global Change Biology, 15(11): 2574-2589. https://doi. org/10.1111/j.1365-2486.2009.01944.x

Ochyra R., Bednarek-Ochyra H., Smith R.I.L. 2008. New and rare moss species from the Antarctic. Nova Hedwigia, 87(3-4): 457-477. https://doi. org/10.1127/0029-5035/2008/0087-0457

Pękal A., Pyrzynska K. 2014. Evaluation of aluminium complexation reaction for flavonoid content assay. Food Analytical Methods, 7: 1776-1782. https://doi. org/10.1007/s12161-014-9814-x

Pizarro M., Rodrigo A., Contreras H., Köhler G., Zúñiga E. 2019. Desiccation tolerance in the Antarctic moss Sanionia uncinate. Biological Research, 52(46): 1-11. https://doi. org/10.1186/s40659-019-0251-6

Robinson S.A., Wasley J., Tobin A.K. 2003. Living on the edge - plants and global change in continental and maritime Antarctica. Global Change Biology, 9(12): 1681-1717. http://dx.doi.org/10.1046/j.1365-2486.2003.00693.x

Robinson S.A., Turnbull J.D., Lovelock C.E. 2005. Impact of changes in natural ultraviolet radiation on pigment composition, physiological and morphological characteristics of the Antarctic moss, Grimmia antarctici. Global Change Biology, 11(3): 476-489. https://doi. org/10.1111/j.1365-2486.2005.00911.x

Robinson S.A., Waterman M.J. 2014. Sunsafe bryophytes: Photoprotection from excess and damaging solar radiation. In: Photosynthesis in Bryophytes and Early Land Plants. Advances in Photosynthesis and Respiration (Including Bioenergy and Related Processes). Eds D. Hanson, S. Rice. Dordrecht: Springer, vol. 37, pp. 113130. https://doi.org/10.1007/978-94-007-6988-5 7
Sabovljević M., Vujičić M., Pantović J., Sabovljević A. 2014. Bryophyte conservation biology: In vitro approach to the ex situ conservation of bryophytes from Europe. Plant Biosystems, 148(4): 1-12. http://dx.doi.org/10.1080/1126 $\underline{3504.2014 .949328}$

Smith R.I.L. 2005. The thermophilic bryoflora of Deception Island: unique plant communities as a criterion for designating an Antarctic Specially Protected Area. Antarctic Science, 17(1): 17-27. https://doi.org/10.1017/ $\underline{\mathrm{S} 0954102005002385}$

Stark L.R. 2017. Ecology of desiccation tolerance in bryophytes: A conceptual framework and methodology. Bryologist, 120(2): 129-164. http://dx.doi. org/10.1639/0007-2745-120.2.129

Su L., Yin J.J., Charles D., Zhou K., Moore J., Yu L. 2007. Total phenolic contents, chelating capacities, and radicalscavenging properties of black peppercorn, nutmeg, rosehip, cinnamon and oregano leaf. Food Chemistry, 100(3): 990-997. $\quad$ http://dx.doi.org/10.1016\%2Fj. foodchem.2005.10.058

Tuba Z., Clack N.G., Stark L.R. 2011. Bryophyte ecology and climate change. New York: Cambridge University Press, xxi + 506 pp. https://doi. org/10.1111/j.1442-9993.2012.02409.x

Waterman M.J., Bramley-Alves J., Miller R.E., Keller P.A., Robinson S.A. 2018. Photoprotection enhanced red cell wall pigments in three east Antarctic mosses. Biological Research, 51(49): 1-13. $\quad$ https://doi.org/10.1186/ s40659-018-0196-1

Wojtaszek P. 2011. Mechanical integration of plant cells and plants. Berlin; Heidelberg: Springer-Verlag, 345 pp. https://doi.org/10.1007/978-3-642-19091-9 8

Yoon J., Sekhon S.S., Kim Y., Min J. 2016. Enhanced lysosomal activity by overexpressed aminopeptidase $\mathrm{Y}$ in Saccharomyces cerevisiae. Molecular Cellular Biochemistry, 417: 181-189. https://doi.org/10.1007/ s11010-016-2728-8

Recommended for publication by O.K. Zolotareva 
Лобачевська О.В., Кияк Н.Я., Кордюм Є.Л., Хоркавців Я.Д. 2020. Роль гравіморфозів у адаптації мохів до екстремальних умов. Український ботанічний журнал, 78(1): 69-79 [In English].

Інститут екології Карпат НАН України, вул Стефаника 11, Львів 79005, Україна: О.В. Лобачевська, Н.Я. Кияк, Я.Д. Хоркавців. Інститут ботаніки ім. М.Г. Холодного НАН України, вул. Терещенківська 2, Київ 01601, Україна: Є.Л. Кордюм

Реферат. Гравічутливість мохів на різних стадіях онтогенезу має пристосувальне значення, що сприяє функціональній активності та стійкості гаметофіту за екстремальних умов мікрооселищ. Метою роботи було визначення участі гравіморфозів в адаптивній пластичності мохів залежно від термальних умов їхніх місцезростань та впливу УФ-опромінення. Об'єктом дослідження була стерильна культура протонеми мохів Weissia tortilis (матеріал зібраний за різних термальних умов на території Запорізької та Львівської областей України), Bryum caespiticium (Львівської області) та B. caespiticium і Polytrichum arcticum (матеріал зібраний в Антарктиці, о-в Галіндес). Проаналізовано гравічутливість протонеми, досліджено морфологічну структуру і морфогенез протонемних столонів. Протонему W. tortilis з двох локацій на території України та $B$. caespiticium 3 Антарктики та України, що знаходилися в різних умовах УФ-опромінення, порівнювали за чутливістю до УФ-радіації. Гравізалежні морфози надземних дендритів W. tortilis в аридних місцезростаннях та галуження апікальних клітин гравітропних столонів антарктичних зразків мохів P. arcticum і B. caespiticium, а також швидкий розвиток пагонів на них є проявом участі гравіморфогенезу в адаптації моху до стресових умов навколишнього природного середовища. Гравічутливість та компетенція до формування бруньок на верхівці гравітропного столону розглядаються як важливий адаптаційний морфогенетичний процес. Встановлено, що рослини $W$. tortilis із Запорізької області більш стійкі до УФ-опромінення, ніж із Львівської області. Для мохів із території Антарктики після УФ-опромінення характерними є значна антиоксидантна активність та підвищений вміст фенольних сполук і флавоноїдів.

Ключові слова: Антарктика, гравіморфогенез, дендрити, протонема, Україна, фенольні сполуки, ультрафіолетове опромінення 
